\title{
CRTC1 transcriptional coactivator is required for hepatitis B virus gene expression and replication
}

\author{
Hei-Man Vincent Tang, Wei-Wei Gao, Chi-Ping Chan, Kin-Hang Kok, Dong-Yan Jin ${ }^{*}$ \\ From Metabolism, Diet and Disease 2014: Cancer and metabolism \\ Washington DC, USA. 28-30 May 2014
}

\section{Background}

Chronic hepatitis B virus (HBV) infection occurs in over 400 million people worldwide, $15-40 \%$ of whom will terminally develop severe liver diseases including hepatocellular carcinoma. Although development of HCC is a multi-step process, high HBV DNA level is a major risk factor for disease progression. Transcription of HBV from the cccDNA template is essential for its replication and requires CREB transcription factor, a master regulator of cell metabolism. However, transcriptional coactivators that facilitate CREB-dependent activation of HBV transcription remain to be identified and characterized.

\section{Results}

In this study we demonstrate that cellular CRTC transcriptional coactivators, which also play important roles in liver metabolism, are required for HBV transcription and replication. CRTC1 expression was elevated in HBV-positive hepatoma cells and liver tissues. Ectopic expression of CRTC1 in HepG2 hepatoma cells stimulated preS2/S promoter activity of HBV, whereas overexpression of a dominant inactive form of CRTC1 resulted in suppression of activity. CRTC1 interacts with CREB and they are mutually required for the recruitment to preS2/S promoter and the activation of HBV transcription. The expression of pregenomic RNA (pgRNA) and the level of cccDNA were upregulated when CRTC1 was overexpressed, whereas the levels of pgRNA, cccDNA and HBsAg were diminished when CRTC1 was compromised. In addition, HBV transactivator protein HBx stabilized CRTC1 and promoted its activity on HBV transcription.

\section{Conclusion}

Our work reveals an essential role of CRTC1 in HBV transcription and an unrecognized link between liver metabolism and HBV oncogenesis mediated through a shared transcriptional coactivator.

\section{Acknowledgements}

The work was supported by Hong Kong HMRF (12111052 and 13121052) and SK YEE Medical Fund (2011).

Published: 28 May 2014

\section{References}

1. Siu YT, Chin KT, Siu KL, Choy EYW, Jeang KT, Jin DY: TORC1 and TORC2 coactivators are required for Tax activation of the human T-cell leukemia virus type 1 long terminal repeats. J Virol 2006, 80:7052-7059.

2. Siu YT, Jin DY: CREB - a real culprit in oncogenesis. FEBS J 2007, 274:3224-3232.

3. Tang HMV, Gao WW, Chan CP, Siu YT, Wong CM, Kok KH, Ching YP, Takemori H, Jin DY: LKB1 tumor suppressor and salt-inducible kinases negatively regulate human T-cell leukemia virus type 1 transcription. Retrovirology 2013, 10:40.

doi:10.1186/2049-3002-2-S1-P31

Cite this article as: Tang et al:: CRTC1 transcriptional coactivator is required for hepatitis B virus gene expression and replication. Cancer \& Metabolism 2014 2(Suppl 1):P31.

Submit your next manuscript to BioMed Central and take full advantage of:

- Convenient online submission

- Thorough peer review

- No space constraints or color figure charges

- Immediate publication on acceptance

- Inclusion in PubMed, CAS, Scopus and Google Scholar

- Research which is freely available for redistribution 